med ulik vekting. Hovedvekten ligger på vanlig røntgen, men også $\mathrm{CT}$ og $\mathrm{MR}$ er omtalt i litt større kapitler. Ultralyd, gjennomlysning, intervensjonsradiologi og nukleærmedisin er kun meget kort beskrevet.

Boken er tilpasset problembasert studieteknikk, og forfatterne angir at et av målene er å gi kunnskap som kan føre til riktig henvisningspraksis og forståelse av nytten av bildediagnostikk i klinisk praksis.

I Norge er og har det vært behov for at leger selvstendig skal kunne tolke konvensjonelle røntgenbilder både i sykehus og i legevaktsammenheng. Radiology at a glance gir en grei innføring i dette, men er ikke uttømmende. I tillegg er ultralyd en modalitet som brukes i stadig flere kliniske spesialiteter, herunder allmennmedisin, og kapitlet om ultralyd er således skuffende kort.

Siden denne er laget med tanke på utdanningen i Storbritannia, refererer den til regelverket der, både når det gjelder strålehygiene og henvisning til bildediagnostikk. Også de eksamensrettede sluttkapitlene er preget av dette. The Royal College of Radiology har utarbeidet retningslinjer for bruk av bildediagnostikk (2007), og disse refereres. Både regelverk og retningslinjer harmonerer imidlertid godt med norsk praksis, og overføringsverdien er derfor stor.

Den konsentrerte formen gjør at mye informasjon formidles til leseren på lite plass, noe som kan være en utfordring i en læresituasjon. Forenkling gir også av og til unøyaktigheter. Men alt $i$ alt er dette en god innføring i radiologi og velegnet for målgruppen. Boken er også godt oppdatert innen et fag i rivende utvikling.

\section{Avansert og utfordrende om avhengighet}

Trevor W. Robbins, Barry J. Everitt, David J. Nutt, red.

The neurobiology of addiction

307 s, tab, ill. Oxford: Oxford University Press, 2010. Pris GBP 45

ISBN 978-0-19-956215-2

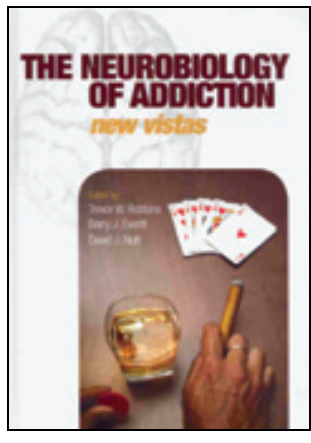

Boken er en oppsummering fra et diskusjonsmøte som ble avholdt i 2008 i Royal Society. På møtet deltok svært mange av verdens ledende forskere innen rusmiddel-nevrobiologi-feltet. Det er ikke angitt noen spesielle målgrupper, men boken henvender seg nok også til dem som står et stykke unna denne forskningen.

Den nevrobiologiske forståelsen av hva som skjer i hjernen under utvikling av rusmiddelavhengighet (addiction) har utviklet seg enormt de siste 10-15 årene. Behovet for en felles diskusjon og oppsummering var bakgrunnen for møtet og dermed boken. Foruten å ha et innlednings- og oppsummeringskapittel, er den organisert $\mathrm{i}$ fire deler rundt temaene: teorier for utvikling av rusmiddelavhengighet, utvidelsen av avhengighetskonseptet til å omfatte nikotin, spill og overspising, sårbarhetsfaktorer for rusmiddelmisbruk og årsaker til og konsekvenser av avhengighet.

Hver del har fire underkapitler, som jevnt over gir en oversikt over dagens forskningsstatus på de aktuelle områdene. Hvert kapittel har forskjellige forfattere, mens redaktørene har tatt seg av innlednings- og oppsummeringskapitlet.

Resultater oppnådd i dyrestudier utgjør hovedtyngden av det som presenteres. Men det gis god plass også til å diskutere hvordan resultater fra dyrestudier kan overføres til avhengighet hos mennesker. Det trekkes for eksempel flere forbindelseslinjer fra nevrobiologi til psykologisk forskning. I del 4 er det også et kapittel som oppsummerer hvordan ny nevrobiologisk viten kan gi opphav til helt nye behandlingsformer for rusmiddelavhengige.

Teksten er krevende $\mathrm{i}$ den forstand at leseren bør ha betydelig innsikt i nevroanatomi, nevrobiologi, farmakologi og forskningsmetoder for å få fullt utbytte. Men selv uten slike detaljkunnskaper får leseren innblikk i et av de mest spennende nevrobiologiske forskningsområdene, der veien fra biologiske oppdagelser til rusmiddelbrukerens daglige liv er kort. Man får også inntrykk av dynamikken i fagfeltet og samtidig innsikt i utfordringer og alt det vi vet for lite om. Alle kapitlene peker på slike utfordringer.

At det er forskjellige forfattere for alle kapitler, gjør at fremstillingen ikke blir pedagogisk enhetlig. Man savner også en gjennomgående linje. Mye av disse manglene rettes imidlertid opp ved den oppsummeringen som gjøres $\mathrm{i}$ avslutningskapitlet. Dette er virkelig en perle.

Boken blir neppe en bestselger. Til det er den for basalt forskningsorientert. Men den kan gi økt innsikt og forståelse samt impulser til mange som jobber i rusmiddelfeltet så sant man ikke går seg vill i prefrontale substrukturer, diverse dopaminreseptorer og intracellulære signalmolekyler.

\section{Jørg Mørland}

Divisjon for rettstoksikologi

og rusmiddelforskning

Nasjonalt folkehelseinstitutt

\section{Forstår vi risiko bedre etter dette?}

Verdens helseorgansisasjon

Risk characterization of microbiological

hazards in food

Guidelines. 119 s, tab, ill. Genève: WHO/FAO,

2010. Pris CHF 35

ISBN 978-92-4-154789-5

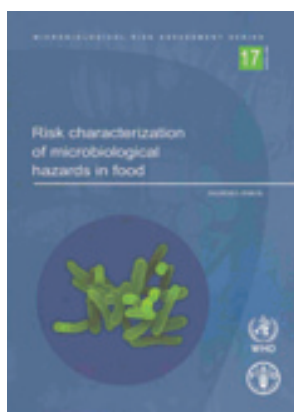

Dette er en del av en serie om mikrobiologisk risikovurdering av mat. Den oppdaterer leseren på teknikken som i dag benyttes for gjennomføring av risikovurderinger på matområdet. Historikken går tilbake til etablering av Verdens handelsorganisasjon (WTO) og etablering av den såkalte SPS-protokollen (sanitære og plantesanitære spørsmål), der bruk av risikovurderinger ble slått fast som den eneste metoden til regulering av internasjonal handel på det biologiske området (mat, planter, levende dyr og dyreprodukter). Alle bøkene i serien må leses innenfor den forståelsen.

Boken gir en nødvendig forståelse av den delvis svært avanserte matematiske teknikken som benyttes ved etablering av slike risikovurderinger. For en som har arbeidet med slike vurderinger, vil boken være en god oppdatering og en påminnelse om kompleksiteten i slike vurderinger, der man egentlig har som mål både å kvantifisere helekonsekvenser av matbårne infeksjoner og intoksikasjoner og også kunne foreslå intervensjoner. Dette er også problemet: De som skal basere sine vedtak på slike risikovurderinger, vil i regelen ikke kunne forstå den matematiske strukturen i slike modeller.

En mer basal kritikk kan også reises mot de modellene som presenteres. I sin struktur er de forståelsesorientert og prøver å tallfeste en serie sannsynligheter og mulige utfall, men de skal benyttes som prediksjoner som basis for intervensjon. De modellene som skisseres, kan imidlertid være en god ramme for diskusjon av handlingsalternativer hvis alternativene og situasjonen er klart nok definert som det i regelen ikke er ved gjennomføring av risikovurderinger. En grunnleggende mangel ved de modellene som presenteres, er at de egentlig løsrives fra en kausalforståelse og ikke kan benyttes direkte. Mikrobiologiske risikovurderinger har lenge vært brukt med suksess for å regulere internasjonal handel med levende dyr og dyreprodukter i forhold til spesifikke patogener. På matområdet har man bare helt unntaksvis benyttet redskapet $i$ regulering av handel - som var intensjonen. Slik flyter derfor risikovurderinger over i bedriftenes lovpålagte kvalitetssystemer. 